\title{
Trophic structure of the fish community throughout the reservoirs and tributaries of the Middle and Lower Tietê River (Sáo Paulo, Brazil)
}

\author{
Estrutura trófica da comunidade de peixes dos reservatórios e tributários do Médio e \\ Baixo Rio Tietê (São Paulo, Brasil)
}

Welber Senteio Smith ${ }^{1,2 *}$, Camila Galvão Francisco Pereira ${ }^{2}$, Evaldo Luiz Gaeta Espindola² and Odete Rocha ${ }^{2,3}$

${ }^{1}$ Laboratório de Ecologia Estrutural e Funcional, Universidade Paulista - UNIP, Campus Sorocaba, Av. Independência, 752, Iporanga, CEP 18103-000, Sorocaba, SP, Brasil

${ }^{2}$ Programa de Pós-graduação em Ciências da Engenharia Ambiental, Escola de Engenharia de São Carlos - EESC, Centro de Recursos Hídricos e Estudos Ambientais - CRHEA, Universidade de São Paulo - USP, Rodovia Domingos Innocentini, Km 13, CEP 13560-970, Itirapina, SP, Brasil

${ }^{3}$ Programa de Pós-graduaçáo em Ecologia e Recursos Naturais, Universidade Federal de São Carlos - UFSCar, Rodovia Washington Luís, Km 235, CP 676, CEP 13565-905, São Carlos, SP, Brasil

*e-mail: welber_smith@uol.com.br

Cite as: Smith, W.S. et al. Trophic structure of the fish community throughout the reservoirs and tributaries of the Middle and Lower Tietê River (São Paulo, Brazil). Acta Limnologica Brasiliensia, 2018, vol. 30, e308.

Abstract: Aim: We investigated the use of food resources throughout the reservoirs and tributaries of the Middle and Lower Tietê River. Methods: The samplings were made in July 2000 (dry period) and January 2001 (rainy period). The fish samples were collected using two batteries of gill nets consisting of 8 nets with 10 meters in length and 1.5 meters wide with different mesh sizes, dip net and dragging nets. The stomach contents were dissected, the portion studied was the stomach and the anterior third of the intestines. Food remains found in the stomach were analyzed under a stereoscopic microscope and its identification was performed to the lowest taxonomic category. Results: The analysis of stomach contents returned 30 types of food sources, being 21 autochthonous and 8 allochthonous. Most of the diet of the species in the tributaries consists of terrestrial insects, followed by vegetal material, seeds, crustaceans and mud, whereas in the reservoirs the main diet consists of aquatic insects, vegetal material, seeds and scales. The species of fish analyzed were grouped into 13 trophic categories. In both reservoirs and tributaries, most of the diet was carnivorous, whereas the omnivorous diet occurred only in the reservoirs. Species from rivers are more specialized and in reservoirs they are more generalist, making it a better survival strategy. Conclusions: Fishes use the coastal areas of the reservoirs and even of the tributaries to feed on superior plants and insects that have terrestrial and aquatic stages. The trophic characteristics exhibited by the fish in the reservoirs depend on the structuring of the community during the colonization process, the characteristics of each reservoir, the introduction of exotic species of fish and alternative food sources.

Keywords: diet; feeding habits; trophic categories; seasonal variation.

Resumo: Objetivo: Investigamos a utilizaçáo dos recursos alimentares, ao longo dos reservatórios do Médio e Baixo Tietê e tributários. Métodos: Os peixes foram capturados utilizando duas baterias de redes de espera com diferentes malhas. O conteúdo estomacal foi obtido pela dissecção do estomago e 
parte do intestino. Os itens alimentares foram analisados no microscópio estereoscópico e a identificação foi realizada até a categoria taxonômica possível. Resultados: $\mathrm{Na}$ análise do conteúdo estomacal foram encontrados 30 tipos de itens alimentares, sendo 22 autóctones e 8 alóctones. Pôde-se constatar que a dieta predominante das espécies nos tributários foi constituída por insetos terrestres, seguida de material vegetal, sementes, crustáceos e lodo, enquanto nos reservatórios a dieta principal foi constituída por inseto aquático, material vegetal, sementes e escamas. As espécies de peixes analisadas foram agrupadas em 13 categorias tróficas. Tanto nos reservatórios quanto nos tributários a dieta predominante foi a carnívora, já a dieta onívora ocorreu somente nos reservatórios. As espécies nos rios especializam-se mais em determinados recursos e nos reservatórios sáo mais generalistas, o que possibilita uma melhor condição de sobrevivência. Conclusóes: Os peixes utilizam as áreas litorâneas dos reservatórios e mesmo dos tributários para se alimentarem consumindo vegetais superiores e insetos que possuem estágios terrestres e aquáticos. As características tróficas exibidas pelos peixes nos reservatórios dependem da estruturação da comunidade durante o processo de colonizaçáo, das características particulares de cada reservatório, da introdução de espécies exóticas de peixes e de outros recursos alimentares.

Palavras-chave: dieta; hábito alimentar; categorias tróficas; variação sazonal.

\section{Introduction}

The Middle and Lower stretch of the Tietê River is characterized by a sequence of reservoirs built from the decade of 1960 on, turning lotic systems into lentic systems (Smith et al., 2014). In reservoirs cascades, the reduction in turbidity and increase in transparency improves the water quality, since part of the nutrients and pollutants are detained in the preceding reservoirs (Smith et al., 2014). These changes affect not only fish community, regarding variety and distribution of species (Smith et al., 2002, 2003a; Agostinho et al., 2016) but also the trophic structure of the community (Pereira et al., 2002).

According to Tundisi (1993), the reservoirs of Upper Paraná are ecosystems that establish different patterns regarding the water renewal time, morphometry and mainly the development of the edge zone. As to seasonality, reservoir level alteration produces changes in the edge zone, modifications in the banks and, in some cases, macrophytes mortality, besides interfering in planktonic, benthonic and fish community succession. Thus, the fish communities are subject to several interferences caused by the reservoir construction (Pelicice et al., 2015). Associated to them, in the Middle and Lower stretches of the Tietê River there is still intense deforestation, discharge of domestic and industrial effluent and introduction of fish species (Smith et al., 2002).

Studies regarding trophic alterations in dams are still scarce (Hahn et al., 1997). Concerning the reservoirs of Middle and Lower Tietê River, there are few studies where the diet ecology (or biology) of the fish species were studied. Among them, Arcifa et al. (1988) which evaluated the feeding of fish community, in the Americana (SP) reservoir formed by Atibaia River, tributary of the Piracicaba River; Braga (1998), which evaluated the feeding of Plagioscion squamosissimus in the Barra Bonita reservoir; Montag \& Barrella (2001), evaluated some fish species of reservoirs of the Tietê River; Pereira et al. (2002), evaluated the trophic alterations of species as a result of reservoirs building, and Smith et al. (2003b) emphasized the importance of the edge zone to feed fishes, Pereira et al. (2004) analyzed the diet of nine species of fish of the Três Irmãos reservoir, Stefani \& Rocha (2009) analyzed the diet of Plagioscion squamosissimus into the Tietê River system.

In dammed environments, changes in quantity and variety of the food resources is expected, affecting biotic interactions (Hahn et al., 1997), once the food supply is a determinant factor in the stabilization and survival of fishes. According to Petrere Júnior \& Ribeiro (1994), a decrease usually occurs in food availability of alloctone origin in dammed systems. Furthermore, some studies have shown that fish assemblages in reservoirs are dominated by species with feeding plasticity (Agostinho et al., 2016; Santos et al., 2017). Considering the reservoirs and tributaries, we expect that there are differences in the origin of food items, the trophic categories of fish species and the proportion of general species and specialists between the two types of systems studied.

\section{Material and Methods}

\subsection{Study area}

The study area covers the Middle and Lower Tietê River stretches, including sampling stations placed upstream from the beginning of the cascade reservoirs, six reservoirs (Barra Bonita, Bariri, Ibitinga, Promissão, Nova Avanhandava 
and Três Irmãos) and seven tributaries (Capivara, Jaú, Iacanga, Jacaré-Guaçú, Dourados, Patos and Cotovelo) (Figure 1). The Table 1 includes the geographic locations and the season of the year when the samplings were made.

\subsection{Data collection and analysis}

Samplings were taken in July 2000 (dry period) and January 2001 (rainy period). Fish catching was performed with two batteries of gill nets containing 8 nets with 10 meters in length and 1.5 meters wide with different mesh sizes $(3.0 \mathrm{~cm} ; 4.0 \mathrm{~cm}$;
$5.0 \mathrm{~cm} ; 6.0 \mathrm{~cm} ; 7.0 \mathrm{~cm} ; 8.0 \mathrm{~cm} ; 10.0 \mathrm{~cm}$ e $12.0 \mathrm{~cm}$, between opposed knots), dip net and dragging nets. The samples were standardized with the purpose of obtaining comparable information between the sample stations. The nets were positioned in the reservoir banks and a few meters away for 12 hours (from 6:00 p.m. to 6:00 a.m. on the following day).

Stomach contents were obtained through laboratory dissection and the portion studied was the stomach and the anterior third of the intestine. Food remains found in the stomach were analyzed under a stereoscopic microscope and its identification

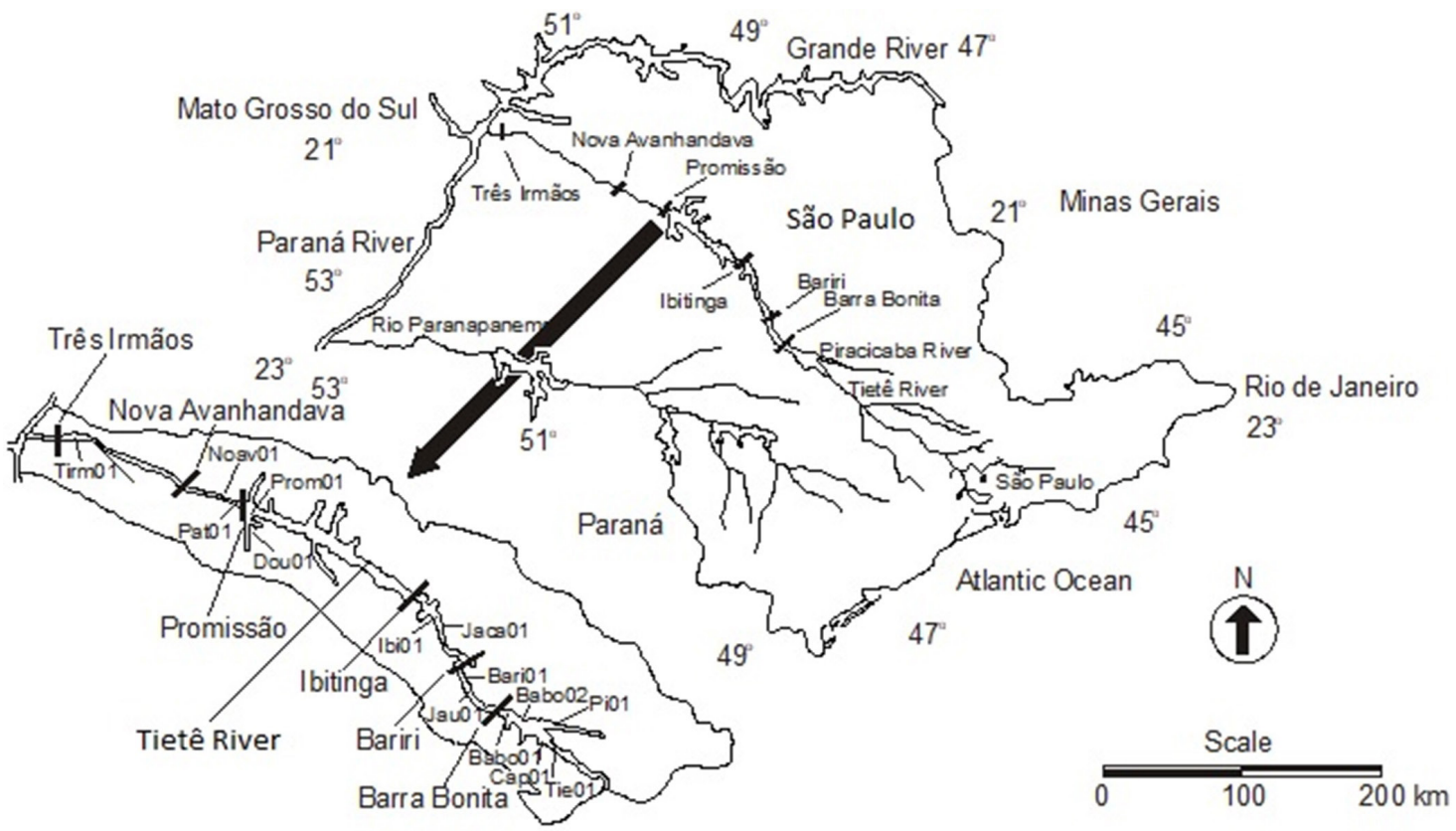

Figure 1. Location of the reservoirs, main tributaries and distribution of the sampling stations in the Tietê River, SP.

Table 1. Codes, site, geographic location of the sampling stations and period of the year in which the samplings were carried out.

\begin{tabular}{|c|c|c|c|c|c|}
\hline \multirow{2}{*}{ Code } & \multirow{2}{*}{ Site } & \multicolumn{2}{|c|}{ Geographic location } & \multirow{2}{*}{ Dry } & \multirow{2}{*}{ Rainy } \\
\hline & & South & East & & \\
\hline Tie01 & Tietê River & $22^{\circ} 39^{\prime} 54.4^{\prime \prime}$ & $48^{\circ} 9^{\prime} 03.4^{\prime \prime}$ & $x$ & - \\
\hline Cap01 & Capivara River & $22^{\circ} 42^{\prime} 40.8^{\prime \prime}$ & $48^{\circ} 22^{\prime} 17^{\prime \prime}$ & $x$ & $x$ \\
\hline Pir01 & Piracicaba River & $22^{\circ} 38^{\prime} 27.1^{\prime \prime}$ & $48^{\circ} 09^{\prime} 51^{\prime \prime}$ & $x$ & $x$ \\
\hline Babo01 & Barra Bonita Reservoir & $22^{\circ} 31^{\prime} 56.2^{\prime \prime}$ & $48^{\circ} 31^{\prime} 05.4^{\prime \prime}$ & $x$ & $x$ \\
\hline Bari01 & Bariri Reservoir & $22^{\circ} 09^{\prime} 51.5^{\prime \prime}$ & $48^{\circ} 45^{\prime} 36^{\prime \prime}$ & $x$ & $x$ \\
\hline Jau01 & Jaú River & $22^{\circ} 11^{\prime} 45.5^{\prime \prime}$ & $48^{\circ} 40^{\prime} 24.6^{\prime \prime}$ & $x$ & $x$ \\
\hline Ibi01 & Ibitinga Reservoir & $21^{\circ} 52^{\prime} 12.7^{\prime \prime}$ & $48^{\circ} 59^{\prime} 05.9^{\prime \prime}$ & - & $x$ \\
\hline Jaca01 & Jacaré-Guaçu River & $21^{\circ} 49^{\prime} 58^{\prime \prime}$ & $48^{\circ} 54^{\prime} 05.9^{\prime \prime}$ & $x$ & - \\
\hline lac01 & lacanga River & $21^{\circ} 52^{\prime} 12.7^{\prime \prime}$ & $48^{\circ} 59^{\prime} 05.9$ & $x$ & - \\
\hline Prom01 & Promissão Reservoir & $21^{\circ} 24^{\prime} 12.6^{\prime \prime}$ & $49^{\circ} 42^{\prime} 19.3^{\prime \prime}$ & $x$ & $x$ \\
\hline Dou01 & Dourado River & $21^{\circ} 24^{\prime} 12.6^{\prime \prime}$ & $49^{\circ} 42^{\prime} 13.3^{\prime \prime}$ & $x$ & $x$ \\
\hline Noav01 & Nova Avanhandava Reservoir & $21^{\circ} 15^{\prime} 43.2^{\prime \prime}$ & $49^{\circ} 51^{\prime} 06.8^{\prime \prime}$ & $x$ & $x$ \\
\hline Pat01 & Dos Patos River & $21^{\circ} 17^{\prime} 15.8^{\prime \prime}$ & $49^{\circ} 50^{\prime} 29.2^{\prime \prime}$ & $x$ & $x$ \\
\hline Ttirm01 & Três Irmãos Reservoir & $20^{\circ} 40^{\prime} 25.2^{\prime \prime}$ & $51^{\circ} 30^{\prime} 06.8^{\prime \prime}$ & $x$ & $x$ \\
\hline Cot01 & Do Cotovelo River & $20^{\circ} 48^{\prime} 24.5^{\prime \prime}$ & $51^{\circ} 04^{\prime} 52.8^{\prime \prime}$ & $\mathrm{X}$ & - \\
\hline
\end{tabular}


was performed to the lowest taxonomic category, considering that the identification of food items was supported by experts. The aquatic insects that could not be identified to the level of order were classified only as 'aquatic insects', the others were classified up to the order level. The diet was analyzed by calculating the amount of stomachs where a certain food item occurs in relation to the overall number of analyzed stomachs (Windell, 1968). Additionally, the biovolume, calculated in $\mathrm{mm}^{3}$, was obtained by the occupied area (area determined with the aid of a millimeter grid) of a specific item calculated relatively to the total area occupied by all items (Kawakami \& Vazzoler, 1980).

With the diet data, the niche range was calculated for each species in all sites sampled according to the Levins' index (Krebs, 1989), whose Formula 1 is:

$\mathrm{B}_{\mathrm{i}}=1 / \Sigma \mathrm{p}^{2} \mathrm{ij}$

wherein: $\mathrm{B}_{\mathrm{i}}=$ Niche range measurement for $\mathrm{i}$-th fish specie; $\mathrm{P}_{\mathrm{ij}}=$ proportions of individuals using the $\mathrm{j}$-th food resource in the $\mathrm{i}$-th fish species.

The index varies from 0 to 1 , where 0 determines the most specialist species and 1 determines the most generalist species, it was considered between 0 and 0.5 specialist and between 0.5 and 1 generalist. The following Formula 2 was used:

$\mathrm{Ba}=\mathrm{B}-1 / \mathrm{n}-1$

where: $\mathrm{Ba}=$ Levin's standardized niche range; $\mathrm{B}=$ Levin's niche range measure; $\mathrm{n}=$ total number of food items used.

The pattern used for food items by fish species in reservoirs was assessed using Principal Component Analysis (PCA), through PAST software version 1.32 (Hammer et al., 2004), using a correlation matrix.

\section{Results}

Twenty-seven species of fish were analyzed in the reservoirs of the Middle and Lower Tietê River and their tributaries. In the analysis of the stomach contents $(\mathrm{N}=295), 30$ types of food items were found. The predominant diet of the species in the tributaries was constituted by 25 items, being terrestrial insects the predominant item. In the reservoirs, 22 items were consumed, being aquatic insects the most consumed item. Most of the items are autochthonous, totaling 22 items, while 8 food items were allochthonous (Table 2).

The predominant items in the reservoirs were debris, filamentous algae, crustaceans, scales and fish, and in tributaries were the plant material, debris, Odonata, aquatic insect (for which it was not possible to identify at the highest level) and aquatic Hemiptera (Figure 2). The fish species were grouped into 13 trophic categories, according to the prevailing food (Figure 3). In the reservoirs the omnivorous category was prevailing for native species while the invasive ones presented insectivorous and carnivorous categories. In tributaries most of the native species were classified in the insectivorous, iliophagous and herbivorous categories while the invaders in the herbivorous and iliophagous categories.

The Principal Component Analysis performed separately with the data from the reservoirs and tributaries (Figure 3 and 4), emphasizing the existence of five dominant trophic categories. The first two components represented $47.33 \%$ of the total variability of the data (Table 3 ). The most important items related positively with the first axis were: Odonata, Crustacea and Ephemeroptera, while negatively were mud and algae. The second axis shows greater relevance of Ephemeroptera, filamentous algae, aquatic insect, Coleoptera and Diptera with positive values and crustaceans with negative value.

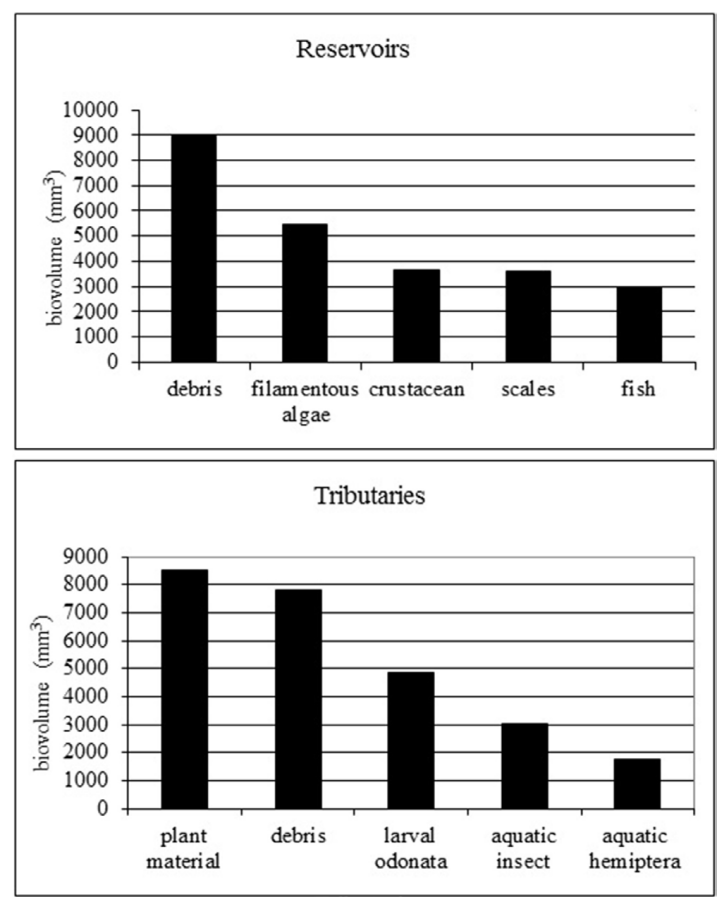

Figure 2. Biovolume of the main items used by fish species in the reservoirs and tributaries of the Middle and Lower Tietê River. 
Table 2. Food item list presented in the tributaries and reservoirs of the Middle and Lower Tietê River and their origin.

\begin{tabular}{|c|c|c|c|c|}
\hline ITEM & Tributaries & Reservoir & Allochthonous & Autochthonous \\
\hline \multicolumn{5}{|l|}{ CLASS INSECTA } \\
\hline Exoskeleton fragment & - & - & - & - \\
\hline Aquatic insect & - & - & & - \\
\hline \multicolumn{5}{|l|}{ Juvenile } \\
\hline Odonata & & - & & - \\
\hline Hemiptera & & - & & - \\
\hline Diptera & - & & & - \\
\hline Ephemeroptera & - & - & & - \\
\hline Coleoptera & - & - & & - \\
\hline Trychoptera & - & - & & - \\
\hline Chironomidae & - & - & & - \\
\hline Diptera & & • & & • \\
\hline \multicolumn{5}{|l|}{ Adult } \\
\hline Chironomidae & - & & & - \\
\hline Hemiptera & - & & & - \\
\hline Terrestrial Coleoptera & & - & - & \\
\hline Ephemeroptera & - & & - & \\
\hline Terrestrial Diptera & • & & - & \\
\hline Trichoptera & - & • & - & \\
\hline Odonata & - & & - & \\
\hline \multicolumn{5}{|l|}{ VEGETABLE MATERIALS } \\
\hline Filamentous algae & - & - & & - \\
\hline Gramineum & - & - & - & \\
\hline Gramineum (seed) & - & • & - & \\
\hline \multicolumn{5}{|l|}{ ZOOPLANKTON } \\
\hline Rotifera & - & - & & - \\
\hline Copepoda & • & • & & - \\
\hline Ostracoda & & • & & - \\
\hline Cladocera & - & & & - \\
\hline \multicolumn{5}{|l|}{ VERTEBRATES } \\
\hline Scales & - & - & & - \\
\hline Fish & - & • & & • \\
\hline \multicolumn{5}{|l|}{ INVERTEBRATES } \\
\hline Crustacea & - & - & & • \\
\hline Gastropoda & - & - & & - \\
\hline Annelida & - & & & \\
\hline \multicolumn{5}{|l|}{ ORGANIC MATERIAL } \\
\hline Sludge & - & - & & - \\
\hline
\end{tabular}

The Principal Component Analysis with the data of the tributaries represented $44.97 \%$ of the total data variability, considering the first two components (Figure 5). When the first axis was considered, the main items were scale, vegetable material, seed and filamentous algae with positive values and crustacean with negative value. In the second component, the most important items were Odonata, crustacean and Ephemeroptera with positive values and sludge with negative value (Table 4). The separation of fish species studied was evidenced in carnivorous, iliophagous, insectivorous and herbivorous (Figure 5).

By comparing the reservoirs with the tributaries, it was observed a greater number of generalist species in the reservoirs and specialists in the tributaries (Figure 6). Both native and invasive species presented, even with a small difference, greater tendency to generalization, and the greatest difference was in the native species (Figure 6).

\section{Discussion}

When studying the reservoirs of the Middle and Lower Tietê River and their tributaries, high diversity of food items consumed by fish species was verified, similar to other studies (Pelicice \& Agostinho, 2006). Here the fish community of reservoirs and tributaries studied also showed predominance of autochthonous items (Hahn et al., 1997), being 


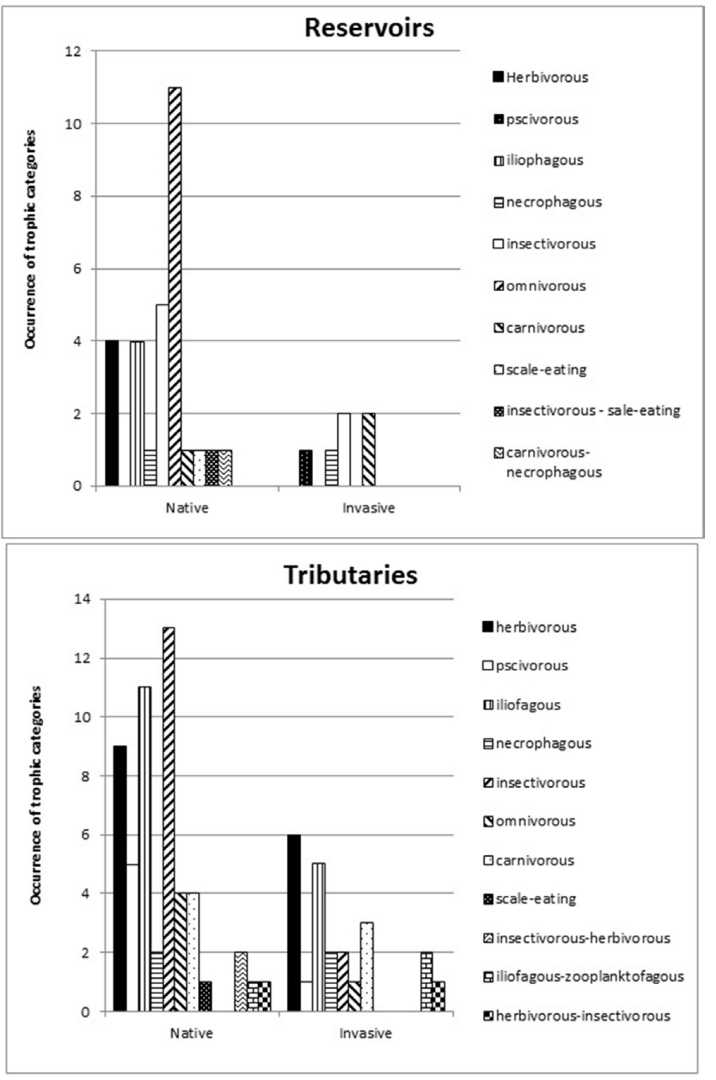

Figure 3. Trophic categories of the native and introduced species in the reservoirs and tributaries of the Middle and Lower Tietê River. items with the highest biovolume in the present study. Species such as Hoplosternum littorale (Hancock, 1828), Cyphocharax modestus (Fernández-Yépez, 1948) and Steindachnerina insculpta (FernándezYépez, 1948) have sufficient amount of food

Table 3. Result of Principal Component Analysis: values obtained for items consumed in the reservoirs in each principal component with the two higher percentages of variances. In bold font are the most important items in the first two major components (CP1 and CP2).

\begin{tabular}{lccc}
\hline \multicolumn{1}{c}{ Items } & Code & CP 1 & CP 2 \\
\hline Fish & pere & -0.01 & -0.11 \\
Crustacean & crusre & $\mathbf{0 . 3 9}$ & -0.27 \\
Efemeroptera & ephre & $\mathbf{0 . 3 5}$ & $\mathbf{0 . 5 3}$ \\
Odonata & odore & $\mathbf{0 . 4 3}$ & 0.01 \\
Filamentous algae & algfre & $\mathbf{- 0 . 3 0}$ & $\mathbf{0 . 4 2}$ \\
Sludge & lodore & $\mathbf{- 0 . 5 7}$ & -0.08 \\
Exoskeleton fragment & fexore & 0.14 & 0.11 \\
Hemiptera & hemre & 0.14 & 0.11 \\
Gastropod & gastre & 0.14 & -0.18 \\
Coleoptera & colre & 0.002 & $\mathbf{0 . 3 4}$ \\
Diptera & dipre & 0.002 & $\mathbf{0 . 3 4}$ \\
Aquatic insect & insare & -0.003 & $\mathbf{0 . 3 8}$ \\
Organic matter & matore & -0.09 & -0.06 \\
Ostracoda & ostrare & -0.17 & 0.05 \\
Chironomidae & quire & -0.17 & 0.05 \\
& & $27.03 \%$ & $20.30 \%$ \\
Total variance & & & $47.33 \%$ \\
\hline
\end{tabular}

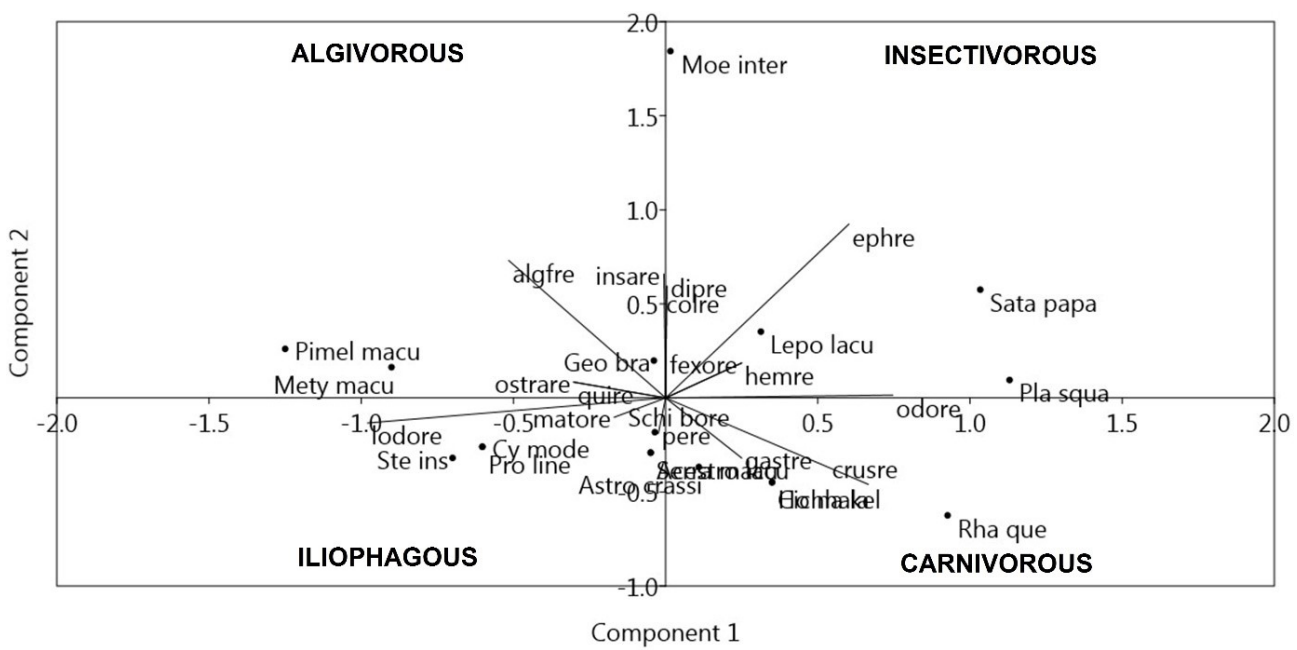

Figure 4. Principal Component Analysis (PCA) diagram of food items used by the species of fish studied in the reservoirs of the Middle and Lower Tietê River. Ste ins (Steindachnerina insculpta); Rha que (Rhamdia quelen); Astro crassi (Astronotus crassipinnis); Pimel macu (Pimelodus maculatus); Pro line (Prochilodus lineatus); Cy mode (Cyphocharax modestus); Serra macu (Serrasalmus maculatus); Sata papa (Satanoperca papaterra); Geo bra (Geophagus brasiliensis); Pla squa (Plagioscion squamosissimus); Mety macu (Metynnis maculatus); Moe inter (Moenkhausia intermedia); Lepo lacu (Leporinus lacustris); Cichla kel (Cichla kelberi); Acestro lacu (Acestrorhynchus lacustres); Schi bore (Schizodon borelli); lodore (sludge); algfre (filamentous algae); ephre (Ephemeroptera); matore (organic matter); crusre (crustacean); insare (aquatic insect); odore (Odonata); dipre (Diptera); pere (fish); fexore (exoskeleton fragment); ostrare (ostracoda); quire (chironomidae); hemre (Hemiptera); gastre (gastropod); colre (terrestrial coleoptera). 


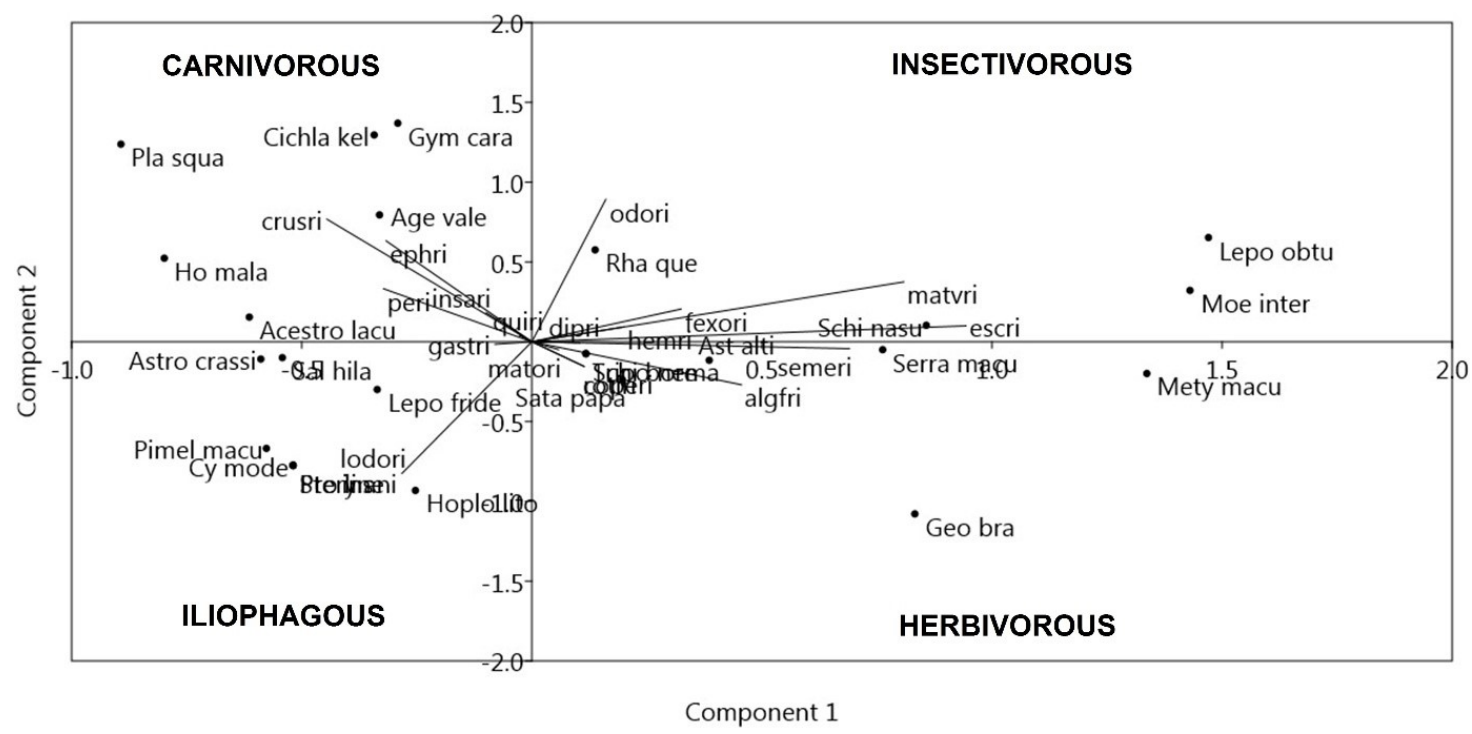

Figure 5. Principal Component Analysis (PCA) diagram of food items used by the fish species studied in the tributaries of the Middle and Lower Tietê River. Ptery ani (Pterygoplichthys anisitsi); Ast alti (Astyanax lacustris); Tripo nema (Tryportheus nematurus); Sal hila (Salminus hilari); Astro crassi (Astronotus crassipinnis); Pimel macu (Pimelodus maculatus); Pro line (Prochilodus lineatus); Cy mode (Cyphocharax modestus); Gym cara (Gymnotus carapo); Hoplo lito (Hoplosternum litoralle); Age vale (Ageneiosus valenciennesi); Serra macu (Serrasalmus maculatus); Sata papa (Satanoperca papaterra); Geo bra (Geophagus brasiliensis); Pla squa (Plagioscion squamosissimus); Schi nasu (Schizodon nasutus); Mety macu (Metynnis maculatus); Moe inter (Moenkhausia intermedia); Asta (Astyanax lacustris); Rha que (Rhamdia quelen); Ho mala (Hoplias malabaricus); Lepo obtu (Leporinus obtusidens); Lepo fride (Leporinus friderici); Cichla kel (Cichla kelberi); Acestro lacu (Acestrorhynchus lacustris); Schi bore (Schisodon borelli); escri (scale); semeri (seed); matvri (vegetal material); lodori (slud); algfri (filamentous algae); ephri (Ephemeroptera); matori (organic matter); crusri (crustacean); insari (aquatic insect); odori (Odonata); dipri (Diptera); peri (fish); fexori (exoskeleton fragment); coperi (copepoda); quiri (chironomidae); hemri (Hemiptera); gastri (gastropod); rotiri (rotifer).
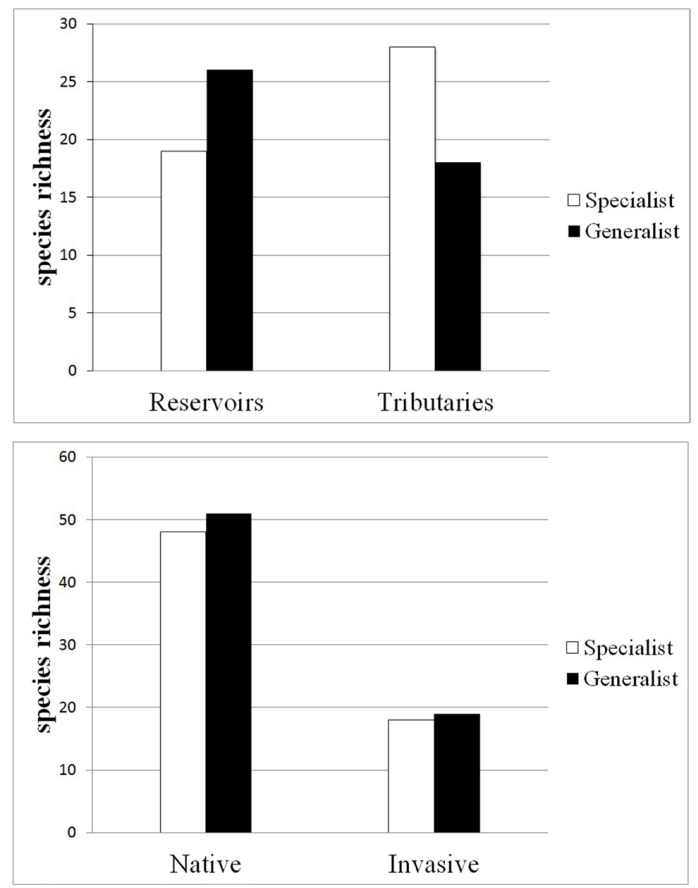

Figure 6. Occurrence of generalist and specialist species comparing the reservoirs and tributaries and the native and invasive species in the Middle and Lower Tietê River, according to Levin's index.
Table 4. Result of Principal Component Analysis: values obtained for items consumed in the tributaries in each principal component with the two largest percentages of variances. In bold the most important items in the first two major components (CP1 and CP2).

\begin{tabular}{lccc}
\hline \multicolumn{1}{c}{ Items } & Code & CP 1 & CP 2 \\
\hline Scale & escri & $\mathbf{0 . 5 5}$ & 0.06 \\
Exoskeleton fragment & fexori & 0.19 & 0.12 \\
Fish & peri & -0.19 & 0.19 \\
Crustacean & crusri & -0.26 & $\mathbf{0 . 4 5}$ \\
Ephemeroptera & ephri & -0.18 & $\mathbf{0 . 3 7}$ \\
Odonata & odori & 0.09 & $\mathbf{0 . 5 2}$ \\
Filamentous algae & algfri & 0.26 & -0.16 \\
Plant material & matvri & $\mathbf{0 . 4 7}$ & 0.22 \\
Seed & semeri & $\mathbf{0 . 4 0}$ & -0.02 \\
Diptera & dipri & 0.06 & -0.004 \\
Organic matter & matori & 0.034 & -0.03 \\
Hemiptera & hemri & 0.12 & 0.05 \\
Gastropod & gastri & -0.05 & -0.01 \\
Sludge & lodori & -0.16 & $-\mathbf{0 . 4 8}$ \\
Aquatico insect & insari & -0.06 & 0.11 \\
Chironomidae & quiri & -0.01 & 0.02 \\
Rotifer & rotiri & 0.07 & -0.09 \\
Copepoda & coperi & 0.07 & -0.09 \\
& & $23.02 \%$ & $21.95 \%$ \\
Total variance & & & $44.97 \%$ \\
\hline & & &
\end{tabular}


regardless of the period and place, with little influence of availability, compared to other items. These species, classified as iliophagous, are very abundant in the first reservoirs (Barra Bonita, Bariri and Ibitinga), acting as sedimentation sites of material in suspension (Smith et al., 2014), retaining the organic matter originated mainly from effluent discharge and carried by leaching, promoting the cycling of matter and nutrients (Luz-Agostinho et al., 2006). The tributaries presented, in the majority, muddy bottom, favoring species that consume debris, such as the above-mentioned ones and also Prochilodus lineatus (Valenciennes, 1836). In a study performed by Resende et al. (1998), in the Miranda River, State of Mato Grosso do Sul, the importance of detritivores fishes was confirmed in relation to the pre-mineralization of the organic matter present in the sludge. These fishes act in the purification of the water courses subject to the environmental pollution (Pereira \& Resende, 1998). This explains the high abundance of the iliophages species in both reservoirs and tributaries and in other places (Carvalho et al., 1998; Alvim \& Peret, 2004).

Gandini et al. (2012) stated that the change in the proportion of resources can cause some trophic guilds to be lost or become restricted to a few species. Nevertheless, the results obtained here to trophic guilds (13 categories) allowed to show that most trophic groups representative for freshwater courses were present in the reservoirs and tributaries studied, suggesting that many species can maintain their food pattern even with relevant environmental changes (Agostinho et al., 2008). Hahn et al. (1998) recognized nine trophic categories in the Itaipu reservoir, which reinforces the statements above, while Vidotto-Magnoni \& Carvalho (2009) in fish communities, the abundance of trophic guilds is very dependent on environmental conditions.

The predominance of the omnivorous category for native species in the reservoirs is in accordance with Arcifa et al. (1988) that also verified the same result in the Salto Grande reservoir, Americana, SP. This is due to the greater generalization of the diet of the fish species in the reservoirs. The best adapted native species to reservoirs present high plasticity in their diet (Lowe-Mcconnell, 1987). The invasive species in the reservoirs were included in the insectivorous or carnivorous trophic category, being that into the Tietê system this species explore different items such as aquatic insects, crustaceans, fish and gastropods. Agostinho et al. (1995) and Hahn et al. (1997) verificaram that the carnivores, represented by the piscivorous ones, are amongst the most abundant species in the Itaipu and Segredo reservoirs, which was not verified in the present study.

The low fish consumption can be explained by the low incidence of predators and by the availability of other food items. The piscivorous species were abundant in the Tietê, as well as in their tributaries, as reported by Monteiro (1953) and Smith et al. (2003a). Smith (2006) showed that species such as Pseudoplatystoma corruscans (Spix \& Agassiz, 1829), Zungaro jahu (Ihering, 1898) and Salminus brasiliensis (Cuvier, 1816) were easily fished in the Middle and Lower Tietê. With the construction of the reservoirs, these species have become rare, reducing their populations and resulting in local extinctions.

The last reservoirs of the cascade system have greater transparency and better conditions (Smith et al., 2014), allowing the further development of the crustaceans, how is the case Três Irmãos reservoir. This reservoir has high transparency, favorable to crustacean development (Pereira et al., 2002; Smith et al., 2003b), which serve as food source to the piscivorous ones like Acestrorhynchus lacustris (Lütken, 1875), Plagioscion squamosissimus (Heckel, 1840) and Cichla kelberi (Kullander \& Ferreira, 2006). Additionally, this reservoir has low abundance of forage species, increasing the use of crustaceans and reinforcings the low consumption of the fish item. Welcomme (1979) reports that abundance of piscivores increases with availability of forage species, which may justify reduced piscivorous predation in the last reservoirs of the cascade like the one of Três Irmãos. Santos \& Formagio (2000) reported the food preference of some species for shrimp. At the Bariri reservoir, Plagioscion squamosissimus, invasive and very dominant species, presented piscivorous feeding behavior, whereas in the Jaú River, a tributary of this reservoir, the species consumed insects, as well as fish (which presented a lower frequency), supporting the hypothesis that the variety of food items available in a lotic environment is superior to the food available in a lentic environment. Stefani \& Rocha (2009) stated that the food plasticity of $P$. squamosissimus may be associated with the fact that this species has been successful in Bariri reservoir, as shown by the great variety of items found in its diet. The feeding habit of this species may be considered piscivorous, however, it consumes other items including aquatic insects and vegetable materials. Bennemann et al. 
(2006) observed that since the introduction of P. squamosissimus in 1992 in the Capivara reservoir (Paranapanema River) that species changed its fish diet especially from Astyanax lacustris (Garutti \& Britski, 2000) to shrimps due to the reduction in the abundance of prey species and the fact that this species is not a selective predator, eating all kinds of preys available.

The tributaries, on the other hand, allows a greater proliferation of insects and the riparian forest or the grasses on the banks provide important sources of vegetal matter mainly for herbivorous species. In the tributaries, most of the native species fell into the carnivorous, insectivorous, iliophagous and herbivorous categories as demonstrated by the Principal Component Analysis. Zavala-Camin (1996) states that in rivers, the insects have important participation in the diet of the fish, being that the larval forms of aquatic life are the main options as a source of food. According to this characterization, it became evident that species in rivers specialize more in certain resources, differently in reservoirs, where they are more generalist. The generalization in the diet allows better survival conditions of the species in the reservoirs. Such fact does not imply that species present specializations to use certain resources, but rather that, since some resources have higher availability, the species use these resources in larger quantity. Regarding invasive species, there was predominance of the herbivorous and iliophagous categories. The results suggest the influence of environmental characteristics on the availability of resources, since they emphasized the importance of plants and insects for fish diet in tributaries while in reservoirs, the species explored more filamentous algae, crustaceans and fishes.

It is worth noting the absence of species that explore directly zooplankton in adult stage and macrophytes. In this study, no species used this resource directly. In the food content of the species analyzed, this item was found in small quantities. Only a few species presented rotifers, copepods in their diet, probably being ingested indirectly with other food. According to Agostinho \& Júlio Júnior (1999) no kind of filter zooplanktofagous species was known in the Alto Paraná until the mapará Hypophthalmus edentatus (Spix \& Agassiz, 1829) began to occur coming from the Middle Paraná. These authors also point out that algae and microcrustaceans, associated with periphyton, seem to have an important role to detritivorous and bentophagous species, such as found in the present study. Araújo Lima et al. (1995) stated that phytoplankton and zooplankton are secondary items in adult fish feeding. According to Welcomme (1979) it is rare to find macrophyte consumers in river fish communities, including tropical ones, though macrophytes are the most abundant plant resource in reservoirs.

Agostinho et al. (1995) found that the feeding of a fish species is based on both the availability and the abundance of food in the environment, and the species may modify their diet according to the characteristics of food offer. A change in diet is a characteristic verified when a river suffers damming, because there are profound changes in the availability of resources (Pereira et al., 2002). Another factor that may be of fundamental importance compared to the resources explored by fish species is the positioning of reservoirs in the cascade, which causes limnologic differences among the reservoirs, also resulting in differences in food resources to be exploited by the fishes (Smith et al., 2003b, 2014). For a complete colonization of the environment, the fish species adapt to current situation by modifying according to the food items available in the site to be colonized. In this situation, the food supply is a key factor in the stabilization and survival of fish in dammed rivers. The reservoirs presented predominance of generalist species. Such species include those, which feed from numerous resources that have temporal and spatial variation, such as insects and grasses. These species may exploit different resources, whether of plant or animal origin, which is a prerequisite for the fish species to inhabit reservoirs. There was higher occurrence of specialization in tributaries. Species that present low diet range have low abundance in reservoirs or apparently disappeared in these stretches. Brycon orbignyanus (Valenciennes in Cuvier \& Valenciennes, 1850) and Myleus tiete (Eigenmann \& Norris, 1900) can be mentioned among these species. These species use fruit and seeds (allochthonous food), and the absence of these fishes in the Tietê River and tributaries is justified especially by the loss of riparian forest. In tributaries, there is a greater availability of allochthonous food. Barrella et al. (2000) state that the riparian forest is one of the most important direct sources of food items while Araújo-Lima et al. (1995) pointed out that the fish community of the Paraná River and its tributaries are mainly composed of specialists, which reinforces the results of this study.

In reservoirs, species become specialists when the resources considered preferred are abundant and these same species may specialize in other 
resources, when they are in other reservoirs and tributaries with distinct trophic characteristics. As an example, we can mention the case of corvina (Plagioscion squamosissimus) having preference for shrimps being characterized as a specialist in the Promissão, Nova Avanhandava and Três Irmãos reservoirs, but behave as a generalist in the Barra Bonita reservoir (where shrimp is scarce). In this reservoir, this species feeds from insects and fishes (Pereira et al., 2002). Braga (1998) characterized Plagioscion squamosissimus as a piscivorous in this same reservoir, emphasizing also the predation of insects. This result reinforces that the positioning of the reservoirs in cascade influences the diet of the species of fish differently from an isolated reservoir.

The generalization of the diet of fish species of the reservoir cascade is mainly due to little variety and availability of food that these ecosystems provide to the fish species. The species Steindachnerina insculpta, Pimelodus maculatus (La Cepède, 1803) and Hoplosternum litoralle kept the same feeding behavior both in the tributaries and in the reservoirs, as they are specialist species in a very common item, not suffering reduction in the change of biotope. The species Astyanax lacustris, Rhamdia quelen (Quoy \& Gaimard, 1824) and Leporinus friderici (Bloch, 1794) remained with the generalist behavior in two different environments. The omnivorism of gender Leporinus has been largely emphasized in the literature (Andrian et al., 1994; Hahn et al., 1998; Durães et al., 2001).

Meschiatti (1995) state that the generalization in the diet is related to the abundance of food items, habitat change and the presence of other species, being this, the ideal behavior, giving advantage to these species in relation to the specialist species. According to Agostinho et al. (1995), the fishes from tropical environments, while exhibiting a marked trophic specialization, show mostly great feeding flexibility. These statements reinforce what has been found by this study, which indicated specialist species are less abundant in reservoirs. Species like Steindachnerina insculpta, Cyphocharax modestus and Schizodon nasutu (Kner, 1858) use very abundant resources in reservoirs such as sediment (sludge) and vegetable material, respectively. These species have been captured mainly in the Barra Bonita, Bariri and Ibitinga reservoirs, since these reservoirs present great amount of organic matter deposited on the bottom, besides grass and macrophytes. In the Promissão, Nova Avanhandava and Três Irmãos reservoirs, they are less abundant, but they are present exploring the organic matter from the macrophyte decomposition. These data demonstrate the large amount of debris available in both reservoirs and tributaries, although few species exploit these resources, especially curimatids and prochilodontids.

\section{Acknowledgements}

We would like to thank all the staff of the CRHEA (Centro de Recursos Hídricos e Ecologia Aplicada) and DEBE (Departamento de Biologia e Ecologia Evolutiva) for their help with this study. This work was supported by FAPESP (99/12112-9), PRONEX/FINEP/ CNPq and PROBIO (MMA/BIRD/GEF).

\section{References}

AgOSTINHO, A.A. and JÚLIO JÚNIOR, H.F. Peixes da bacia do alto rio Paraná. In: R.H. LOWEMCCONNELL, ed. Estudos ecológicos de comunidades de peixes tropicais. São Paulo: EDUSP, 1999, pp. 374-400.

AGOSTINHO, A.A., GOMES, L.C. and PELICICE, F.M. Ecologia e manejo de recursos pesqueiros em reservatórios do Brasil. Maringá: EDUEM, 2007, $501 \mathrm{p}$.

AGOSTINHO, A.A., GOMES, L.C., SANTOS, N.C., ORTEGA, J.C. and PELICICE, F.M. Fish assemblages in Neotropical reservoirs: colonization patterns, impacts and management. Fisheries Research, 2016, 173, 26-36. http://dx.doi.org/10.1016/j. fishres.2015.04.006.

AGOsTINHO, A.A., PELICICE, F.M. and GOMES, L.C. Dams and the fish fauna of the Neotropical region: impacts and management related to diversity and fisheries. Brazilian Journal of Biology $=$ Revista Brasileira de Biologia, 2008, 68(4), 1119-1132, Supplement. http://dx.doi.org/10.1590/S151969842008000500019. PMid:19197482.

Agostinho, A.A., VAZZOLER, A.E.A.M. and THOMAZ, S.M. The high river Paraná Basin: limnological and ichthyological aspects. In: J.G. TUNDISI, C.E.M. BICUDO and T. MATSUMURA-TUNDISI, eds. Limnology in Brazil. Rio de Janeiro: ABC/SBL, 1995, pp. 59-103.

ALVIM, M.C.C. and PERET, A.C. Food resources sustaining the fish fauna in a section of the upper São Francisco River in Três Marias, MG, Brazil. Brazilian Journal of Biology = Revista Brasileira de Biologia, 2004, 64(2), 195-202. http://dx.doi.org/10.1590/ S1519-69842004000200003. PMid:15462291.

ANDRIAN, I.D.F., DÓRIA, C.D.C., TORRENTE, G. and FERRETTI, C.M.L. Espectro alimentar e similaridade na composição da dieta de quatro espécies de Leporinus (Characiformes, Anostomidae) 
do rio Paraná $\left(22^{\circ} 10^{\prime}-22^{\circ} 50^{\prime} S / 53^{\circ} 10^{\prime}-53^{\circ} 40^{\prime} \mathrm{W}\right)$, Brasil. Revista Unimar, 1994, 16(3), 97-106.

ARAÚJO LIMA, C.A.R.M., AGOSTINHO, A.A. and FABRÉ, N.N. Tropic aspects of fish comunnities in Brazilian rivers and reservoirs. In: J.G. TUNDISI, C.E.M. BICUDO and T. MATSUMURATUNDISI, eds. Limnology in Brazil. Rio de Janeiro: ABC/SBL, 1995, pp. 105-136.

ARCIFA, M.S., FROEHICH, O. and NORTHCOLE, T.G. Distribution and feeding ecology of fishes in a tropical Brazilian reservoir. Memorias de la Sociedad de Ciencias Naturales La Salle, 1988, 48(2), 301-326.

BARRELLA, W., PETRERE JÚNIOR, M., SMITH, W.S. and MONTAG, L.F.A. As relaçóes entre as matas ciliares, os rios e os peixes. In: R.R. RODRIGUES and LEITÁO-FILHO, H.F., eds. Matas ciliares: conservação e recuperação. São Paulo: EDUSP/FAPESP, 2000, pp. 187-207.

BENNEMANN, S.T., CASATTI, L. and OLIVEIRA, D.C. Alimentação de peixes: proposta para análise de itens registrados em conteúdos gástricos. Biota Neotropica, 2006, 6(2), 1-8. http://dx.doi. org/10.1590/S1676-06032006000200013.

BRAGA, F.M.S. Alimentação de Plagioscion squamosissimus (Osteichthyes, Sciaenidae) no reservatório de Barra Bonita, Estado de São Paulo. Iheringia: Série Zoologia, 1998, 84, 11-19.

CARVALHO, E.D., SILVA, V.F.B., FUJIHARA, C.Y., HENRY, R. and FORESTI, F. Diversity of fish species in the River Paranapanema-Jurumirim Reservoir transition region (São Paulo, Brazil). Italian Journal of Zoology, 1998, 65(1), 325-330. http:// dx.doi.org/10.1080/11250009809386841.

DURÃES, R., POMPEU, P.S. and GODINHO, A.L. Alimentação de quatro espécies de Leporinus (Characiformes, Anostomidae) durante a formação de um reservatório no sudeste do Brasil. Iheringia: Série Zoologia, 2001, 90(90), 183-191. http://dx.doi. org/10.1590/S0073-47212001000100019.

GANDINI, C.V., BORATTO, I.A., FAGUNDES, D.C. and POMPEU, P.S. Estudo da alimentação dos peixes no rio Grande à jusante da usina hidrelétrica de Itutinga, Minas Gerais, Brasil. Iheringia: Série Zoologia, 2012, 102(1), 56-61. http://dx.doi. org/10.1590/S0073-47212012000100008.

HAHN, N.S. and FUGI, R. Alimentação de peixes em reservatórios brasileiros: alteraçóes e consequências nos estágios iniciais do represamento. Oecologia Brasiliensis, 2007, 11(4), 469-480. http://dx.doi. org/10.4257/oeco.2007.1104.01.

HAHN, N.S., AGOSTINHO, A.A., GOMES, L.C. and BINI, L.M. Estrutura trófica da ictiofauna do reservatório de Itaipu (Paraná-Brasil) nos primeiros anos de sua formação. Interciência, 1998, 23(5), 299-305.
HAHN, N.S., FUGI, R., ALMEIDA, V.L.L., RUSSO, M.R. and LOUREIRO, V.E. Dieta e atividade alimentar de peixes do reservatório de Segredo. In: A.A. AGOSTINHO and L.C. GOMES, eds. Reservatório de Segredo: bases ecológicas para o manejo. Maringá: EDUEM, 1997, pp. 141-162.

HAMMER, Ø., HARPER, D.A.T. and RYAN, P.D. PAST: Palaeontological Statistics, version 1.32 [online]. Oslo: Universitetet i Oslo, 2004. [viewed 10 Sept. 2005]. Available from: http://folk.uio.no/ohammer/ past/

HIGUTI, J., ZVIEJKOVSKI, I.P., TAKAHASHI, M.A. and DIAS, V.G. Chironomidae indicadora de estado trófico em reservatórios. In: L. RODRIGUES, S.M. THOMAZ, A.A. AGOSTINHO and L.C. GOMES, eds. Biocenoses em reservatórios: padróes espaciais e temporais. São Carlos: RiMa, 2005, pp. 137-145.

KAWAKAMI, E. and VAZZOLER, G. Método gráfico e estimativa de índice alimentar aplicado no estudo de alimentação de peixes. Boletim do Instituto Oceanográfico, 1980, 29(2), 205-207. http://dx.doi. org/10.1590/S0373-55241980000200043.

KREBS, C.J. Ecological methodology. New York: Harper \& Row Publishers, 1989, 650 p.

LOWE-MCCONNELL, R.H.L. Ecological studies in tropical fish communities. Cambridge: Cambridge University Press, 1987, 382 p. http://dx.doi. org/10.1017/CBO9780511721892.

LUZ-AGOSTINHO, K.D.G., BINI, L.M., FUGI, R., AGOSTINHO, A.A. and JÚliO JÚNIOR, H.F. Food spectrum and trophic structure of the ichthyofauna of Corumbá reservoir, Paraná river Basin, Brazil. Neotropical Ichthyology, 2006, 4(1), 61-68. http://dx.doi.org/10.1590/S167962252006000100005 .

MESCHIATTI, A.J. Alimentação da comunidade de peixes de uma lagoa marginal do Rio Mogi- Guaçu, SP. Acta Limnologica Brasiliensia, 1995, 8, 115-137.

MONTAG, L.F.A. and BARRELLA, W. Ecologia alimentar de cinco espécies de peixes em reservatórios do rio Tietê (SP). Ciências Bioógicas e do Ambiente, 2001, 3(1), 53-65.

MONTEIRO, F.S. Contribuição ao estudo da pesca no rio Piracicaba [Tese de Doutorado]. Piracicaba: Escola Superior de Agronomia "Luiz de Queiroz", Universidade de São Paulo, 1953, 76 p.

PELICICE, F.M. and AGOSTINHO, A.A. Feeding ecology of fishes associated with Egeria spp. patches in a tropical reservoir, Brazil. Ecology Freshwater Fish, 2006, 15(1), 10-19. http://dx.doi.org/10.1111/ j.1600-0633.2005.00121.x.

PELICICE, F.M., AGOSTINHO, A.A. and THOMAZ, S.M. Fish assemblages associated with Egeria in a tropical reservoir: investigating the effects of plant biomass and diel period. Acta Oecologica, 
2005, 27(1), 9-16. http://dx.doi.org/10.1016/j. actao.2004.08.004.

PELICICE, F.M., POMPEU, P.S. and AGOSTINHO, A.A. Large reservoirs as ecological barriers to downstream movements of Neotropical migratory fish. Fish and Fisheries, 2015, 16(4), 697-715. http:// dx.doi.org/10.1111/faf.12089.

PEREIRA, C.G.F., SMITH, W.S. and ESPÍNDOLA, E.L.G. Alteraçóes tróficas nas espécies de peixes em decorrência da construção de reservatórios em cascata do Médio e Baixo Tietê. In: PPG-CEA, ed. Recursos hidroenergéticos: usos, impactos e planejamento integrado. São Carlos: RiMa, 2002, pp. 29-42. Série Ciências da Engenharia Ambiental, vol. 1.

PEREIRA, C.G.F., SMITH, W.S. and ESPÍNDOLA, E.L.G. Hábitos alimenticios de nueve especies de peces del embalse de Três Irmãos, São Paulo, Brasil. Universidad y Ciência, 2004, 1, 33-38.

PEREIRA, R.A.C. and RESENDE, E.K. Peixes detritivoros da planície inundável do rio Miranda, Pantanal, Mato Grosso do Sul, Brasil. Corumbá: EMBRAPA-CPAP, 1998, 50 p. Boletim de Pesquisa, vol. 12.

PETRERE JÚNIOR, M. and RIBEIRO, M.C.L.B. The impact of a large tropical hydroeletric dam: the case of Tucuruí in the middle river Tocantins. Acta Limnologica Brasiliensia, 1994, 5, 123-133.

RESENDE, E.K., PEREIRA, R.A.C. and ALMEIDA, V.L.L Peixes herbivoros de planície inundável do rio Miranda, Pantanal, Mato Grosso do Sul, Brasil. Corumbá: EMBRAPA-CPAP, 1998, 24 p. Boletim de Pesquisa, vol. 10.

SANTOS, G.B. and FORMAGIO, P.S. Estrutura da ictiofauna dos reservatórios de Salto Grande, com ênfase no estabelecimento de peixes piscívoros exóticos. Informe Agropecuário, 2000, 21(203), 98-106.

SANTOS, N.C.L., SANTANA, H.S., ORTEGA, J.C.G., DIAS, R.M., STEGMANN, L.F., ARAÚJO, I.M.S., SEVERI, W., BINI, L.M., GOMES, L.C. and AGOSTINHO, A.A. Environmental filters predict the trait composition of fish communities in reservoir cascades. Hydrobiologia, 2017, 802(1), 245 253. http://dx.doi.org/10.1007/s10750-017-3274-4.

SMITH, W.S. A pesca no rio Tietê. Ciência Hoje, 2006, 38(223), 20-27.

SMITH, W.S., ESPÍNDOLA, E.L.G. and ROCHA, O. Environmental gradient in reservoirs of the medium and low Tietê River: limnological differences through the habitat sequence. Acta Limnologica Brasiliensia, 2014, 26(1), 73-88. http://dx.doi.org/10.1590/ S2179-975X2014000100009.

SMITH, W.S., ESPÍNDOLA, E.L.G., PEREIRA, C.C.G.F. and ROCHA, O. Os impactos dos reservatórios do médio e baixo rio Tietê (SP) na composição das espécies de peixes e na atividade de pesca. In: PPG-CEA, ed. Recursos hidroenergéticos: usos, impactos e planejamento integrado. São Carlos: RiMa, 2002, pp. 57-72.

SMITH, W.S., ESPÍNDOLA, E.L.G. and ROCHA, $O$. Fishing modification due to dam, pollution and introduction fish species in the Tietê River, SP, Brasil. In: C.A. BREBIA, ed. River basin management II. Southampton: WIT Press, 2003a, pp. 389-400.

SMITH, W.S., PEREIRA, C.C.G.F., ESPÍNDOLA, E.L.G. and ROCHA, O. A importância da zona litoral para a disponibilidade de recursos alimentares à comunidade de peixes em reservatórios. In: R. HENRY, ed. Ecótonos nas interfaces dos ecossistemas aquáticos. São Carlos: RiMa, 2003b, pp. 233-248.

STEFANI, P.M. and ROCHA, O. Diet composition of Plagioscion squamosissimus (Heckel, 1840), a fish introduced into the Tietê River system. Brazilian Journal of Biology = Revista Brasileira de Biologia, 2009, 69(3), 805-812. http://dx.doi.org/10.1590/ S1519-69842009000400007. PMid:19802439.

TUNDISI, J.G. Represas do Paraná superior: limnologia e bases científicas para o gerenciamento. In: A. BOLTOVSKOY \& H.L. LOPEZ, eds. Conferências de Limnologia. La Plata: Unlp/Conycept, 1993, pp. 41-52.

VIDOTTO-MAGNONI, A.P. and CARVALHO, E.D. Aquatic insects as the main food resource of fish the Community in a Neotropical reservoir. Neotropical Ichthyology, 2009, 7(4), 701-708. http://dx.doi. org/10.1590/S1679-62252009000400020.

WELCOMME, R.L. Fisheries ecology of floodplain rivers. London: Longman, 1979.

WINDELL, J.T. Food analysis and rate digestion. In: W.E. RICKER, ed. Methods of assessment of production in freshwaters. Oxford: Blackwell, 1968, pp. 197-203.

ZAVALA-CAMIN, L.A. Introdução aos estudos sobre alimentação natural em peixes. Maringá: EDUEM, 1996.

Received: 30 January 2018 Accepted: 03 October 2018 